\title{
Using Satellite Imagery to Estimate Consumptive Water Use from Irrigated Lands in the Milk River Basin, United States and Canada
}

\section{Project Overview}

The U.S. Geological Survey, with the support of the International Joint Commission, and in cooperation with Alberta Environment and Parks, Blackfeet Nation, Environment and Climate Change Canada, and Montana Department of Natural Resources and Conservation, is leading a project that should improve information available to apportion water between Canada and the United States in the St. Mary and Milk River Basins. One component of the water budget, consumptive use of irrigation water (the amount of supplemental water used by crops), can be estimated at 100-meter resolution almost every week using imagery recorded by satellites from 1985 to present (2021) and weather data, when conditions permit. Better estimates of consumptive water use should improve understanding of water availability and use in the basin and should assist with water apportionment procedures.

\section{Milk River Basin Project Timeline and Goals}

- Phase 1, completed in 2020, focused on obtaining and preparing the input datasets required for the consumptive water-use estimates (using an energy balance model, SSEBop; Senay and others, 2013). An example of SSEBop output is shown in figure 1 for the Colorado River Basin, United States.

- Phase 2 is in progress and should be completed in the spring and summer of 2021 and 2022, when in situ data associated with irrigated lands in the Milk River Basin should be collected. These data will be used to potentially improve and verify the consumptive-use estimates derived from SSEBop.

- Phase 3 is planned to begin in 2023 with a focus on running and optimizing the SSEBop model for the upper Milk River Basin. An easy-to-use web application is expected to be developed for anyone to be able to obtain and visualize current and historical consumptive-use data in the basin.

Important note: this project is not an examination of water rights or licenses.
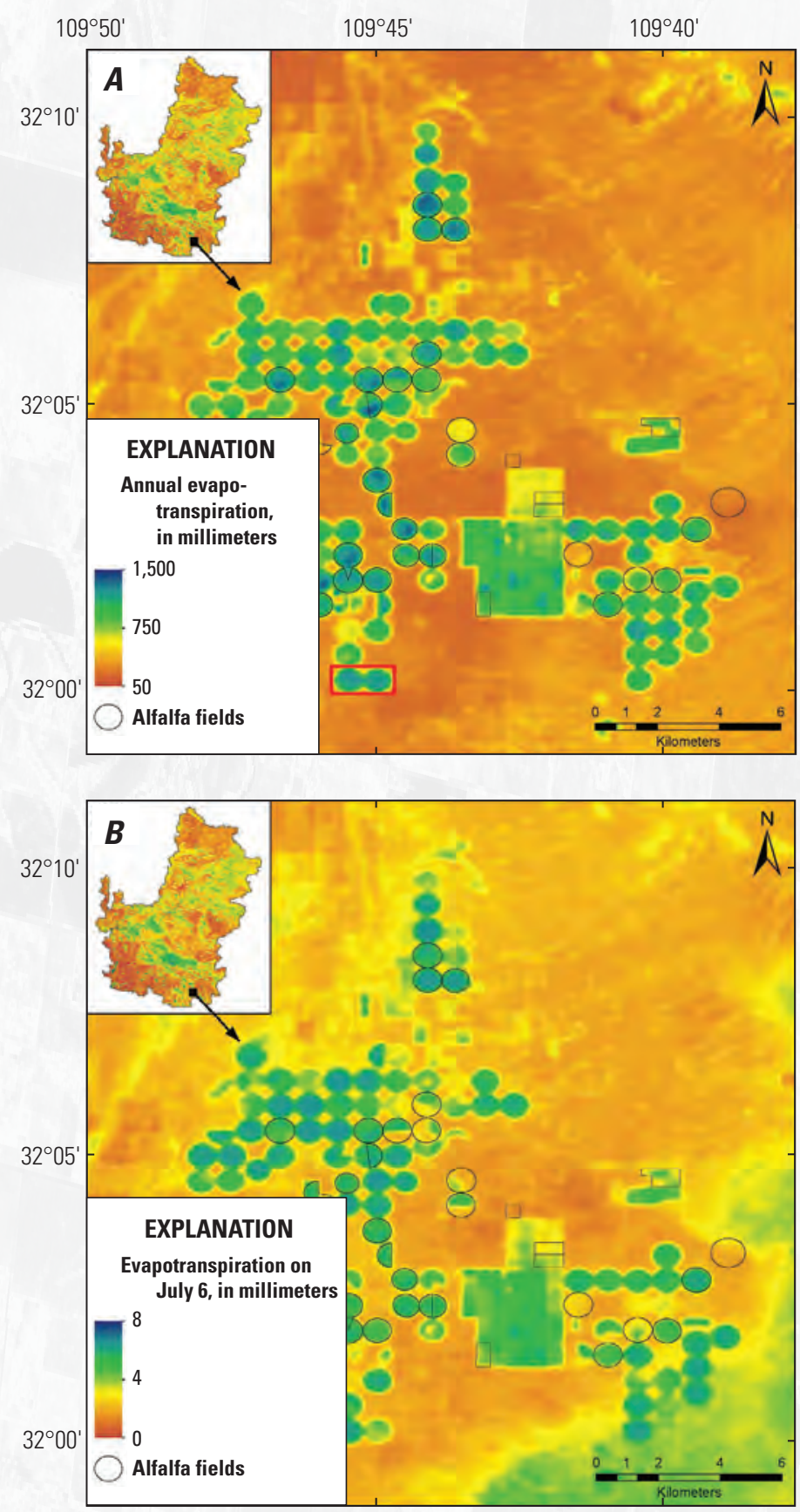

Figure 1. Spatial distribution of evapotranspiration within a selected part of the Southern Willcox irrigation district, Colorado River Basin. From Senay and others (2016). A, annual evapotranspiration. Red box indicates the area shown in Senay and others (2016) figure 8. B, evapotranspiration on July 6, 2013. 


\section{Expected Outcomes}

- A historical database of consumptive water use in the St. Mary and Milk River Basins.

- Biweekly or monthly estimates of current consumptive water use using the newly expanded SSEBop model.

- An online, interactive web application using historical database and biweekly or monthly estimates to allow irrigators, resource managers, and the public to visualize and compare current and historical conditions in the basin.

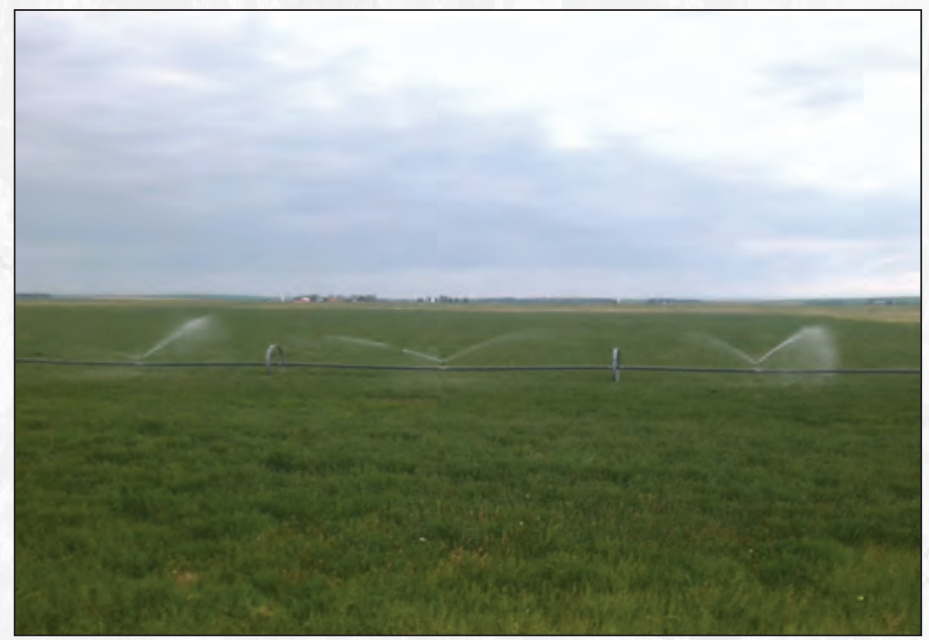

Wheel-line irrigation system actively irrigating a field in the Milk River Basin.

\section{Materials Related to this Project}

- Eyes on Earth podcast, episode 43, "U.S.-Canada Water Use” (U.S. Geological Survey, 2021).

- "Using Satellites to Measure How Thirsty Crops are in the St. Mary-Milk Rivers Region” (Bunch, 2020).

- Project web page.

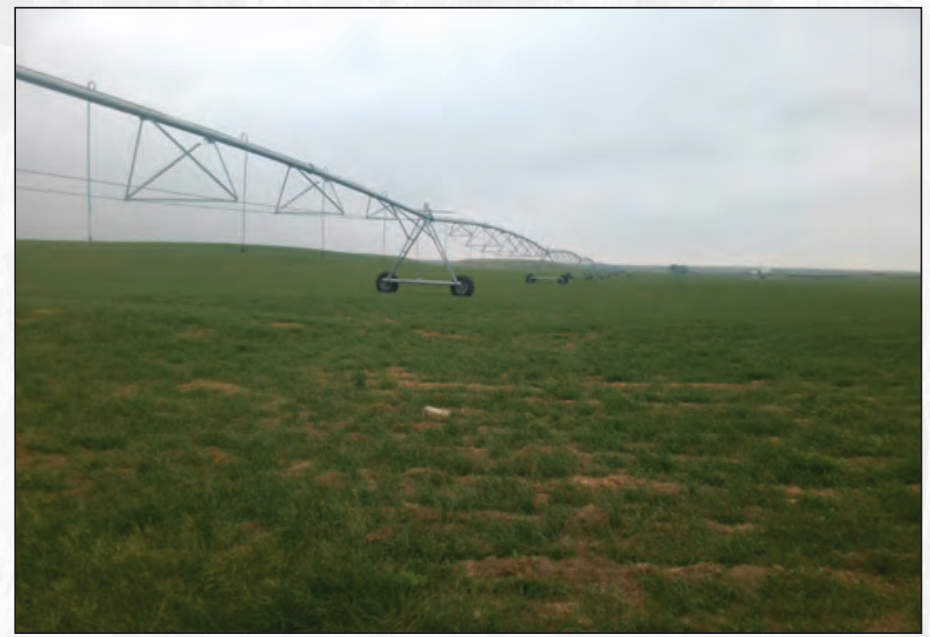

Center-pivot sprinkler system actively irrigating a field in the Milk River Basin.

\section{References Cited}

Bunch, K., 2020, Using satellites to measure how thirsty crops are in the St. Mary-Milk Rivers region: International Joint Commission, Water Matters newsletter, published November 16, 2020, accessed June 2021 at https://ijc.org/en/using-satellites-measure-how-thirstycrops-are-st-mary-milk-rivers-region.

Senay, G.B., Bohms, S., Singh, R.K., Gowda, P.H., Velpuri, N.M., Alemu, H., and Verdin, J.P., 2013, Operational evapotranspiration mapping using remote sensing and weather datasets-A new parameterization for the SSEB approach: Journal of the American Water Resources Association, v. 49, no. 3, p. 577-591, accessed June 2021 at https://doi.org/10.1111/jawr.12057.

Senay, G.B., Friedrichs, M., Singh, R.K., and Velpuri, N.M., 2016, Evaluating Landsat 8 evapotranspiration for water use mapping in the Colorado River Basin: Remote Sensing of Environment, v. 185, p. 171-185, accessed July 2021 at https://doi.org/10.1016/ j.rse.2015.12.043.

U.S. Geological Survey, 2021, U.S.-Canada water use: U.S. Geological Survey, Eyes on Earth podcast, episode 43, released February 8, 2021, 00:15:39, accessed June 2021 at https://www.usgs.gov/media/ audio/eyes-earth-episode-43-us-canada-water-use.

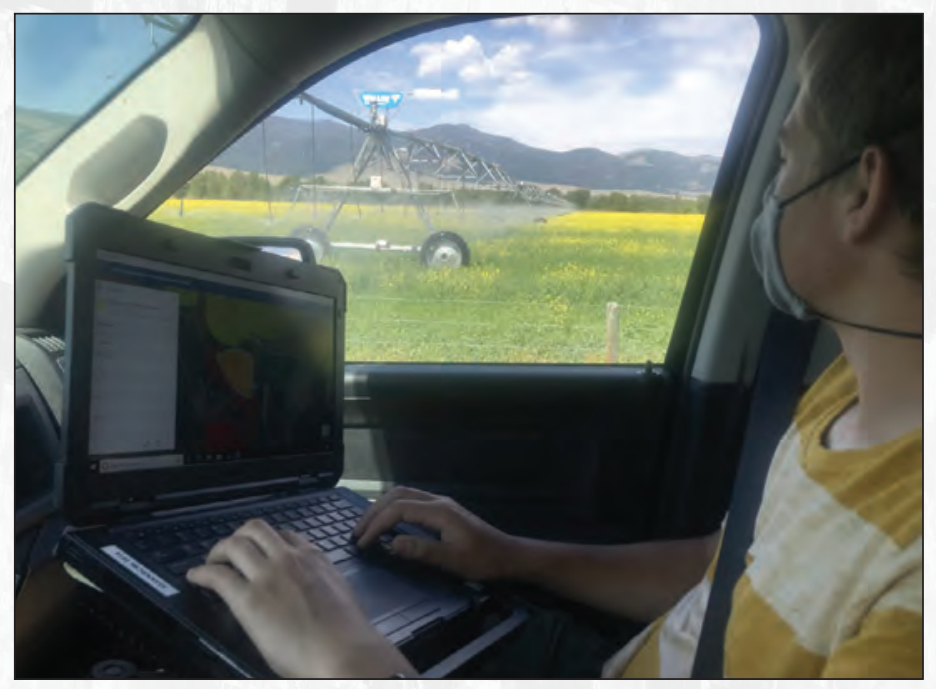

U.S. Geological Survey employee in a vehicle doing irrigation mapping on a laptop.

By Roy Sando,

MacKenzie Friedrichs, and

Gabriel B. Senay

For more information about this publication, contact: Director, USGS Wyoming-Montana Water Science Center 3162 Bozeman Avenue

Helena, MT 59601

406-457-5900

For additional information, visit: https://www.usgs.gov/centers/ wy-mt-water/

Publishing support provided by the Rolla Publishing Service Center 